\title{
Pulmonary position cryopreserved homografts: Durability in pediatric Ross and non-Ross patients
}

\author{
Elif Seda Selamet Tierney, MD, ${ }^{*}$ Welton M. Gersony, MD, Karen Altmann, MD, David E. Solowiejczyk, MD, \\ Laura M. Bevilacqua, MD, ${ }^{*}$ Chava Khan, Ehud Krongrad, MD, Ralph S. Mosca, MD, Jan M. Quaegebeur, MD, PhD, and \\ Howard D. Apfel, MD
}

\footnotetext{
From the Divisions of Pediatric Cardiology and Pediatric Cardiac Surgery, Children's Hospital of New York, Columbia University, College of Physicians and Surgeons, New York, NY.

Received for publication Nov 17, 2004; revisions received March 19, 2005; accepted for publication April 1, 2005.

Address for reprints: Elif Seda Selamet Tierney, MD, Children's Hospital Boston, Department of Cardiology, 300 Longwood Ave, Boston, MA 02155 (E-mail: Seda. Tierney@cardio.chboston.org).

*Current address: Children's Hospital, Boston, Mass.

J Thorac Cardiovasc Surg 2005;130:282-6

$0022-5223 / \$ 30.00$

Copyright $\odot 2005$ by The American Association for Thoracic Surgery

doi:10.1016/j.jtcvs.2005.04.003
}

Objective: The purpose of this study was to evaluate the outcome and risk factors for implant failure in pediatric patients who underwent pulmonary position homograft placement for right ventricular outflow tract obstruction compared with conduit placement as a component of the Ross operation. Actuarial 5-year survivals for cryopreserved right ventricle-to-pulmonary artery homografts range from 55\% to 94\% at all ages. It is not known whether there is a difference in homograft durability when utilized for right ventricular outflow tract obstruction or as part of the Ross operation.

Methods: The records of all pediatric patients receiving a right ventricle-topulmonary artery homograft from July 1989 through October 2003 were reviewed. Ninety-eight consecutive patients were studied (26 Ross, 72 non-Ross). In addition to Ross versus non-Ross comparisons, other potential risk factors for homograft failure analyzed included age at operation, follow-up time, type of surgery, and homograft type and size.

Results: Ross and non-Ross patients were comparable in age at the time of the operation and follow-up time. Homograft failure rates were $12 \%$ and $51 \%$ for Ross and non-Ross patients, respectively. Freedom from reintervention was $93 \%$ in the Ross and 66\% in the non-Ross group at 5 years $(P=.019)$. On multivariate analysis, non-Ross operation and age less than 2 years were significant predictors of homograft failure.

Conclusions: 1. Pediatric patients undergoing the Ross operation have longer homograft survival than pediatric patients treated for right ventricular outflow tract obstruction, independent of age. 2. Homografts placed in patients less than 2 years of age have shorter homograft survival.

I n 1966, Ross and Somerville ${ }^{1}$ reported the first use of an aortic homograft to establish right ventricle-to-pulmonary artery continuity in a patient with tetralogy of Fallot and pulmonary atresia. Since that time, pulmonary position homografts have been used in a variety of right-sided congenital heart lesions. Actuarial 5-year homograft survivals for cryopreserved homografts are reported to range between $55 \%$ and $94 \%,{ }^{2-23}$ with the shortest durability noted in patients less than 2 years of age. ${ }^{4}$

Pulmonary position homografts also are used to replace pulmonary autografts explanted to repair left-sided outflow disease (the Ross operation). Several factors may be likely to favor increased pulmonary conduit durability in Ross patients compared with those with right ventricular outflow tract obstruction, including later age at operation (allowing for larger homografts), more normal pulmonary artery architecture, absence of severe right ventricular hypertrophy, and more natural positioning of the homograft. However, this concept has not been systematically 
TABLE 1. Patient characteristics

\begin{tabular}{|c|c|c|c|c|c|c|c|c|}
\hline & $\begin{array}{c}\text { Ross } \\
(n=26)\end{array}$ & $\begin{array}{c}\text { Non-Ross } \\
(\mathrm{n}=72)\end{array}$ & $\begin{array}{c}\text { TOF } \\
(n=37)\end{array}$ & $\begin{array}{l}\text { Rastelli } \\
(\mathrm{n}=23)\end{array}$ & $\begin{array}{l}\text { Truncus } \\
(\mathrm{n}=11)\end{array}$ & $\begin{array}{c}\text { PS } \\
(n=1)\end{array}$ & $P$ value* & $\begin{array}{c}\text { Total } \\
(n=98)\end{array}$ \\
\hline Age at operation (y) & $3.4 \pm 3.4$ & $2.1 \pm 0.3$ & $2.3 \pm 2.5$ & $2.7 \pm 2.4$ & $0.09 \pm 0.3$ & 3.1 & .2 & $2.3 \pm 2.7$ \\
\hline Homograft size (mm) & $19.2 \pm 3.9$ & $16.5 \pm 4.8$ & $16.5 \pm 4.6$ & $18.1 \pm 4.3$ & $13.0 \pm 5.5$ & 18 & .02 & $17.3 \pm 4.7$ \\
\hline Pulmonary type homograft & $19(73 \%)$ & $29(40 \%)$ & $16(43 \%)$ & $9(39 \%)$ & $3(27 \%)$ & 1 & .01 & $48(49 \%)$ \\
\hline Follow-up time (y) & $5.2 \pm 4.0$ & $4.8 \pm 3.8$ & $5.5 \pm 4.0$ & $4.8 \pm 4.4$ & $5 \pm 3.6$ & 4.7 & .7 & $5.1 \pm 3.9$ \\
\hline
\end{tabular}

Values are presented as means \pm SD where shown. TOF, Tetralogy of Fallot variant; $P S$, pulmonary stenosis. *Ross versus non-Ross.

studied. Only a small number of Ross and non-Ross patients have been compared, and these were in the context of a broad study of cryopreserved homografts in the pulmonary position. ${ }^{5}$ The present study directly compares Ross versus non-Ross homograft survival in pediatric patients followed serially after surgical intervention during the first decade of life.

\section{Methods}

The hospital records of all patients less than 10 years of age receiving primary cryopreserved right ventricle-to-pulmonary artery homografts at Children's Hospital of New York from July 1989 through October 2003 were reviewed. Cryopreserved homografts were obtained from Cryolife, Inc (Kennesaw, Ga). All patients who were followed up for longer than 4 months were included in the study unless graft failure occurred earlier $(n=5)$. Hospital records, including operative reports, catheterization data, and echocardiographic studies, were retrospectively reviewed. The study protocol was reviewed and approved by the institutional review board. Ninety-eight consecutive patients were included in the study.

Homograft failure was defined as need for surgical replacement or catheter balloon dilatation and/or stent implantation because of right ventricular outflow tract obstruction. Indications for intervention were determined by the primary cardiologist on the basis of the presence of right ventricular hypertrophy and 2-dimensional and Doppler echocardiographic evidence of significant outflow tract obstruction. In addition to Ross versus non-Ross comparisons, age at operation, length of follow-up, type of operation, homograft type, and size were analyzed as other potential risk factors for homograft failure.

Statistical analysis was performed with the SAS 8.2 software (SAS Institute). Continuous variables were compared between subjects with and without graft failure by using unpaired $t$ test. Categorical variables were compared by the Fisher's exact test. Kaplan-Meier curves were constructed for graft survival, and the effect of Ross versus non-Ross operation, as well as other potential covariates, was assessed by Cox proportional hazards models. Variable selection was performed by backwards elimination for multivariate modeling. Values are presented as means \pm SD.

\section{Results}

Ninety-eight patients were included in the study (Table 1). Twenty-six patients underwent the Ross procedure for left-sided heart disease. Seventy-two patients with right ventricular outflow tract obstruction (non-Ross group) were studied.

The mean follow-up time was 5.1 years (range, 1.25 months-14.7 years) for all patients (Table 1). The 2 groups were comparable in age at the time of the operation (3.4 \pm 3.4 vs $2.1 \pm 0.3$ years, $P=.2)$ and follow-up time (5.2 \pm 4 vs $4.8 \pm 3.8$ years, $P=.7$; Table 1 ). Figure 1 demonstrates the age distribution, which was not statistically different between the Ross and non-Ross groups. The homograft size was greater in the Ross group $(19.2 \pm 3.9$ vs $16.5 \pm 4.8 \mathrm{~mm}, P=.02)$, and more pulmonary type homografts were used in the Ross group (73\% vs $40 \%, P=$ .01 ; Table 1).

The non-Ross group consisted of 3 major groups (Table 1): patients undergoing homograft placement as a component of the Rastelli procedure $(\mathrm{n}=23)$, variants of tetralogy of Fallot $(n=37)$, or truncus arteriosus $(n=11)$ repair. Patients with truncus arteriosus were the youngest in this group ( $0.09 \pm 0.3$ years), and these patients had smaller homografts placed $(13.0 \pm 5.5 \mathrm{~mm})$.

The characteristics of patients with homograft failure are listed in Table 2. The overall homograft failure rate was $41 \%$. Three (12\%) patients in the Ross group had failure of

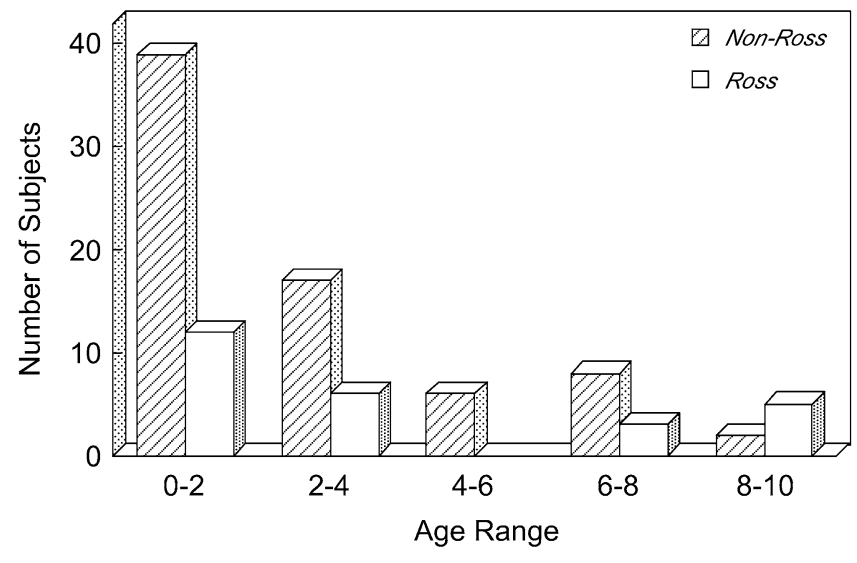

Figure 1. Age distribution of the patients. 
TABLE 2. Homograft failure

\begin{tabular}{lccccccr}
\hline & $\begin{array}{c}\text { Ross } \\
(\mathbf{n}=\mathbf{3})\end{array}$ & $\begin{array}{c}\text { Non-Ross } \\
(\mathbf{n}=\mathbf{3 7 )}\end{array}$ & $\begin{array}{c}\text { TOF } \\
(\mathbf{n = 2 0 )}\end{array}$ & $\begin{array}{c}\text { Rastelli } \\
(\mathbf{n}=\mathbf{9})\end{array}$ & $\begin{array}{c}\text { Truncus } \\
(\mathbf{n}=\mathbf{7})\end{array}$ & $\begin{array}{c}\text { PS } \\
(\mathbf{n}=\mathbf{1})\end{array}$ & $\begin{array}{c}\text { Total } \\
(\mathbf{n}=\mathbf{4 0})\end{array}$ \\
\hline Homograft failure (\%) & $12 \%$ & $51 \%$ & $54 \%$ & $39 \%$ & $64 \%$ & $1 / 1$ & $41 \%$ \\
Age at operation (y) & $4.1 \pm 4.8$ & $2.0 \pm 2.3$ & $2.1 \pm 2.6$ & $1.9 \pm 1.8$ & $0.14 \pm 0.4$ & 3.1 & $2.2 \pm 2.5$ \\
Homograft size (mm) & $20.3 \pm 4.6$ & $15.6 \pm 5.4$ & $16 \pm 5.5$ & $17.3 \pm 5.2$ & $12.0 \pm 4.8$ & 18 & $16.0 \pm 5.5$ \\
Pulmonary type homograft & $3(100 \%)$ & $15(41 \%)$ & $9(45 \%)$ & $2(22 \%)$ & $3(43 \%)$ & $1 / 1$ & $18(45 \%)$ \\
Failure time from operation (mo) & $83.0 \pm 38$ & $53.2 \pm 47$ & $52.4 \pm 50$ & $57.1 \pm 50$ & $50.0 \pm 46$ & 56 & $55.4 \pm 47$ \\
\hline
\end{tabular}

Values are presented as means \pm SD where shown. TOF, Tetralogy of Fallot variant; PS, pulmonary stenosis.

the homograft, whereas 37 (51\%) in the non-Ross group had failure of the homograft. Patients in the Ross group experienced failure at a mean of $83.0 \pm 38$ months after the operation, whereas those in the non-Ross group experienced failure at a mean of $53.2 \pm 47$ months after the operation (Table 2). At the time of homograft failure, the maximum instantaneous homograft gradient, as determined by Doppler echocardiography, was $90.7 \pm 10 \mathrm{~mm} \mathrm{Hg}$ in the Ross group and $67.9 \pm 29 \mathrm{~mm} \mathrm{Hg}$ in the non-Ross group $(P=$ .2). Intervention was required in $8(8 \%$, all in the non-Ross group) patients within 6 months, in 18 (18\%, all in the non-Ross group) patients within 3 years, and in 40 (41\%, 37 in the non-Ross group and 3 in the Ross group) patients within 6 years. There was no significant difference in reintervention rates among the different non-Ross procedures.

Homograft survival at 5 years was $93 \%$ in the Ross group (median follow-up time, 52.9 months) and 66\% in the non-Ross group (median follow-up time, 61.3 months), as shown in the actuarial graph $(P=.019$, Figure 2$)$.

On univariate analysis, non-Ross operation, age less than 2 years at the time of the operation, smaller homograft size, and an aortic-type homograft were significant risk factors for homograft failure; on multivariate analysis, non-Ross

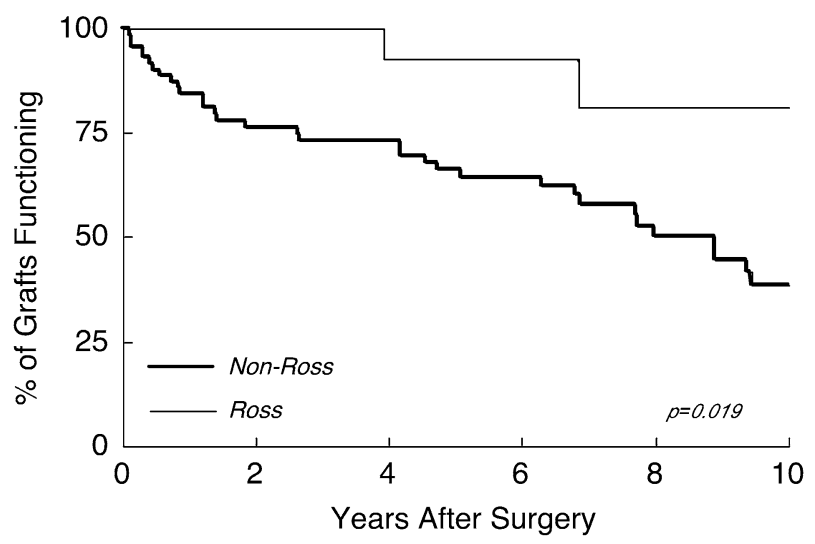

Figure 2. Freedom from homograft intervention stratified according to type of operation $(P=.019)$. operation and age less than 2 years independently remained significant to predict homograft failure (Table 3).

There were 9 infants in the Ross group $(4.1 \pm 3.9$ months; median age, 4 months), of whom only 1 (11\%) patient experienced homograft failure during the follow-up period ( 8 months old at the time of the operation, homograft failure 121 months after the operation). Of 27 infants in the non-Ross group ( $2.6 \pm 3.7$ months; median age, 1 month), $15(55 \%)$ experienced homograft failure within an average of $56.7 \pm 44$ months after the operation.

\section{Discussion}

Over the past 15 years, the Ross operation has become the operation of choice for children and young adults with left-sided outflow tract disease. The increased popularity of this procedure is largely due to the efficacy of the Ross operation in relieving left ventricular outflow tract obstruction in children, the pulmonary autograft's potential for growth, and greater experience with the technical demands of the operation. In addition, the relatively low risk for later right ventricle-to-pulmonary artery conduit replacement has generated less concern over the placing of a second valve at risk (by replacement of the normal native pulmonary artery with a valved conduit) and has contributed to the preference for this procedure. The latter factor appears to stem from a general sense that pulmonary circulation conduits fare better in Ross patients than in others.

Although the idea that Ross patients have greater right ventricular conduit durability has been anecdotally noted in several reports, ${ }^{2,6,7}$ it has never been formally documented. The most likely reason for this is that conduit outcome reviews have predominantly studied older patients in the Ross group and younger ones in the non-Ross group. Since conduits generally last longer in older patients, irrespective of diagnosis or surgical procedure, ${ }^{5}$ there is a bias favoring Ross patients on initial univariate analysis. This is usually confirmed on multivariate analysis, in which the Ross procedure variable is lost, whereas age at operation and conduit size remain significant predictors. For example, Niwaya and colleagues $^{2}$ reviewed the results of 331 (259 Ross and 72 
TABLE 3. Risk factors for homograft failure

\begin{tabular}{|c|c|c|c|c|}
\hline & \multicolumn{2}{|c|}{ Univariate analysis } & \multicolumn{2}{|c|}{ Multivariate analysis } \\
\hline & Hazard ratio $(95 \% \mathrm{Cl})$ & $P$ value & Hazard ratio $(95 \%$ CI) & $P$ value \\
\hline Non-Ross & $4.08(1.26-13.24)$ & .019 & $4.07(1.25-13.23)$ & .020 \\
\hline Age $<2$ y & $2.26(1.18-4.35)$ & .015 & $2.26(1.17-4.34)$ & .015 \\
\hline Aortic homograft & $2.30(1.15-4.60)$ & .018 & - & - \\
\hline Smaller homograft size & $2.72(1.44-5.16)$ & .002 & - & - \\
\hline
\end{tabular}

$\mathrm{Cl}$, Confidence interval.

non-Ross) patients who underwent right ventricle-to-pulmonary artery conduit placement for various indications (median age, 14 years; 38 patients were less than 3 years old) and reported that young age and non-Ross operation were risk factors for failure. However, on multivariate analysis, the use of an aortic homograft, younger age, and later year of operation were the only risk factors for homograft dysfunction. With reasoning similar to that discussed above, Forbess and coworkers ${ }^{5}$ used age of the patient to stratify the implant population into younger and older patient groups. However, a final comparison of the groups was not possible because of insufficient patient numbers, with only 9 patients in the Ross group being less than 10 years of age.

The present study was specifically designed to analyze right ventricular conduit outcomes in Ross and non-Ross group patients of comparable age and conduit size. In order to best assess for differences in conduit durability, we focused on the patient population known to be most susceptible to conduit failure, those less than 10 years of age. On multivariate analysis, the non-Ross procedure and age less than 2 years were shown to be significant independent predictors of worse outcome.

A common explanation offered for the superior conduit durability in Ross patients has emphasized the placement of the homograft in the orthotopic pulmonary position in the right ventricular outflow tract. One might also speculate that sternal compression of the more anteriorly placed conduits could play a role in the earlier failure of non-Ross conduits. A study by Carr-White and colleagues ${ }^{24}$ in 2001 suggested that the predominant mechanism of homograft stenosis was a poorly understood inflammatory reaction. This suggestion was based on their noting of early onset of stenosis, rapid clinical progression, as well as magnetic resonance images and histology of explanted homografts. The cause of the inflammation was unclear; however, early postoperative stretching and lengthening of the homograft causing release of tissue factors was one possibility suggested. It is possible to speculate that the extent of that phenomenon might relate to the degree of peripheral vascular distortion present. To further tease out that possibility, one would need to analyze in detail the degree of architectural abnormality in the group of patients with right-sided outflow tract disease and search for an association with conduit failure. The current retrospec- tive nature of this study and limited patient number prevented that analysis from being attempted here. Such information might be useful, for example, in deciding to forego conduit placement in patients considered at risk for early conduit failure and instead consider more technically challenging approaches to achieving direct right ventricle-to-pulmonary artery continuity.

We thank Dr Robert Sciacca for the statistical analysis of this project.

\section{References}

1. Ross DN, Somerville JC. Correction of pulmonary atresia with a homograft aortic valve. Lancet. 1966;2:1446-7.

2. Niwaya K, Knott-Craig CJ, Lane MM, Chandrasekaren K, Elkins RC. Cryopreserved homograft valves in the pulmonary position: risk analysis for intermediate-term failure. J Thorac Cardiovascular Surg. 1999;117:141-7.

3. Kirklin JW, Blackstone EH, Maehara T, Pacifico AD, Kirklin JK, Pollock S, Stewart RW. Intermediate-term fate of cryopreserved allograft and xenograft valved conduits. Ann Thorac Surg. 1987;44:598606.

4. LeBlanc JG, Russell JL, Sett SS, Potts JE. Intermediate follow-up of right ventricular outflow tract reconstruction with allograft conduits. Ann Thorac Surg. 1998;66(suppl 1):S174-8.

5. Forbess JM, Shah SS, St Louis JD, Jaggers JJ, Ungerleider RM. Cryopreserved homografts in the pulmonary position: determinants of durability. Ann Thorac Surg. 2001;71:54-60.

6. Oury JH, Hiro SP, Maxwell JM, Lamberti JL, Duran CMG. The Ross procedure: current registry results. Ann Thorac Surg. 1998;66(suppl): S162-5.

7. Elkins RC. The Ross operation: applications to children. Semin Thorac Cardiovasc Surg. 1996;8:345-9.

8. Chan WC, Fyfe DA, McKay CA, Sade RM, Crawford FA. Right ventricular outflow reconstruction with cryopreserved homografts in pediatric patients: intermediate term follow-up with serial echocardiographic assessment. J Am Coll Cardiol. 1994;24:483-9.

9. Bando K, Danielson GK, Schaff HV, Mair DD, Julsrud PR, Puga FJ. Outcome of pulmonary and aortic homografts for right ventricular outflow tract obstruction. J Thorac Cardiovasc Surg. 1995;109:509-18.

10. Tweddell JS, Pelech AN, Frommelt PC, Mussatto KA, Wyman JD, Fedderly RT, et al. Factors affecting longevity of homograft valves used in right ventricular outflow tract reconstruction for congenital heart disease. Circulation. 2000;102(suppl III):III130-5.

11. Schorn K, Yankah AC, Alexi-Meskhishvili V, Weng Y, Lange PE, Hetzer R. Risk factors for early degeneration of allografts in pulmonary circulation. Eur J Cardiothorac Surg. 1997;11:62-9.

12. Kay PH, Ross DN. Fifteen years experience with the aortic homograft: the conduit of choice for right ventricular outflow reconstruction. Ann Thorac Surg. 1985;40:360-5.

13. Bull C, Macartney FJ, Horvath P, Almeida R, Merrill W, Douglas J, et al. Evaluation of long term results of homograft and heterograft valves in extracardiac conduits. J Thorac Cardiovasc Surg. 1987;94:12-9. 
14. Cleveland DC, Williams WG, Razzouk AJ, Trusler GA, Rebeyka IM, Duffy L, et al. Failure of cryopreserved homograft valved conduits in the pulmonary circulation. Semin Thorac Cardiovasc Surg. 1992; 86(suppl II):II150-3.

15. Daenen W, Narine K, Goffin Y, Gewillig M. Right ventricular outflow reconstruction with homografts. Eur J Cardiothorac Surg. 1995;9: 448-52.

16. Danielson GK, Anderson BJ, Schleck CD, Ilstrup DM. Late results of pulmonary ventricle to pulmonary artery conduits. Semin Thorac Cardiovasc Surg. 1995;7:162-7.

17. Hawkins JA, Bailey WB, Dillon T, Schwartz DC. Midterm results with cryopreserved allograft valved conduits from the right ventricle to the pulmonary arteries. J Thorac Cardiovasc Surg. 1992;104:910-6.

18. Homann M, Haehnel JC, Mendler N, Paek SU, Holper K, Meisner H, et al. Reconstruction of the RVOT with valved biological conduits: 25 years experience with allografts and xenografts. Eur J Cardiothorac Surg. 2000;17:624-30.

19. Stark J, Bull C, Stajevic M, Jothi M, Elliott M, de Leval M. Fate of subpulmonary homograft conduits: determinants of late homograft failure. J Thorac Cardiovasc Surg. 1998;115:506-16.

20. Sinzobahamvya N, Wetter J, Blaschczok HC, Cho M, Brecher AM, Urban AE. The fate of small-diameter homografts in the pulmonary position. Ann Thorac Surg. 2001;72:2070-6.

21. Perron J, Moran AM, Gauvreau K, del Nido PJ, Mayer JE, Jonas RA. Valved homograft conduit repair of the right heart in early infancy. Ann Thorac Surg. 1999;68:542-8.

22. Albert JD, Bishop DA, Fullerton DA, Campbell DN, Clarke DR. Conduit reconstruction of the right ventricular outflow tract. $J$ Thorac Cardiovasc Surg. 1993;106:228-36.

23. Baskett RJ, Ross DB, Nanton MA, Murphy DA. Factors in early failure of cryopreserved homografts pulmonary valves in children: preserved immunogenicity? J Thorac Cardiovasc Surg. 1996;112:1170-8.

24. Carr-White GS, Kilner PJ, Hon JKF, Rutledge T, Edwards S, Burman $\mathrm{ED}$, et al. Incidence, location, pathology, and significance of pulmonary homograft stenosis after the Ross operation circulation. Circulation. 2001;104(suppl I):I16-20.

\section{Online-www.aats.org}

Now you can get The Journal of Thoracic and Cardiovascular Surgery online. The Journal online brings you faster delivery time, easy searching of current and back issues, links to PubMed, AATS, WTSA, and other important sites, and more. Visit the Journal online today.

\section{Receive tables of contents by e-mail}

To receive the tables of contents by e-mail, sign up through our Web site at http://www.mosby.com/jtcvs

Choose E-mail Notification

Simply type your e-mail address in the box and click the Subscribe button.

Alternatively, you may send an e-mail message to majordomo@mosby.com.

Leave the subject line blank and type the following as the body of your message: subscribe jtcvs_toc

You will receive an e-mail to confirm that you have been added to the mailing list.

Note that TOC e-mails will be sent out when a new issue is posted to the Web site. 